\title{
Grouping Pseudomonas syringae Strains by Comparing DNA Homology at the hrp Gene Cluster and Its Neighboring Regions
}

\author{
Yasuhiro INOUE*,** and Yuichi TAKIKAWA*
}

\begin{abstract}
We compared the structure and homology of the hrp gene cluster and its neighboring region for grouping Pseudomonas syringae pathovars. Cosmid clones selected from genomic libraries constructed for P. syringae pv. glycinea, pv. maculicola and pv. tabaci covered a genomic region of more than $80 \mathrm{~kb}$ that was homologous to $h r p$ genes and neighboring regions in pv. phaseolicola. Comparison of restriction sites and homologies of this large genomic region revealed that the structures of the hrp gene clusters of pv. glycinea, pv. phaseolicola and pv. tabaci closely resemble each other, whereas that of pv. maculicola is distinct from those of the other three pathovars. Hybridization probes derived from pv. phaseolicola and pv. maculicola were used for grouping 32 pathovars of $P$. syringae by Southern hybridization analysis. Patterns of hybridization signal strength suggested that $P$. syringae pathovars can be classified into at least the following three groups : strains having strong homologies to probes from pv. phaseolicola (group I), strains having strong homologies to probes from pv. maculicola (group II) and strains having moderate to no homology to probes from either of the pathovars (group U).
\end{abstract}

(Received July 27, 1998 ; Accepted November 9, 1998)

Key words: Pseudomonas syringae, grouping, DNA homology, hrp cluster and its neighboring regions.

\section{INTRODUCTION}

Pseudomonas syringae has a number of pathovars that are distinct in their host plants and/or disease symptoms. P. syringae is identified with several characteristics such as fluorescent pigment production, lack of soft rotting of potato and a positive hypersensitive reaction on tobacco plant, but each pathovar and strain has considerable phenotypic variations in its nutritional and physiological characteristics ${ }^{3,9,24,29)}$. In recent years, DNA-DNA hybridization and the polymerase chain reaction technique have been used to distinguish the strains or pathovars of the $P$. syringae group bacteria and to classify $P$. syringae into several groups ${ }^{7,8,10,14)}$.

Causing disease on host plants and eliciting the hypersensitive response (HR) on non-host plants are fundamental features controlled by the $h r p$ genes of $P$. syringae. Originally describing the hrp genes in $P$. s. pv. phaseolicola $(P s p)$ by Lindgren et al. ${ }^{16)}$, indicated that Tn5-induced mutants of PSp had lost both the ability to induce halo-blight disease on host plants and the HR on non-host plants. Furthermore, these mutants were complemented by cosmid clones from a genomic library of the wild-type strain, resulting in isolation of a cluster of $h r p$ genes localized in about the $20 \mathrm{~kb}$ DNA region ${ }^{16}$. Thereafter, Lindgren et $a l .{ }^{17)}$ reported that sequences homologous to DNA segments derived from this region were detected in many pathovars of $P$. syringae, and that a Tn5-induced mutation of an hrp gene was transferred from the mutant clone of Psp to $P$. s. pv. glycinea $(P s g)$ and $P$. s. pv. tabaci (Pst) strains by marker exchange mutagenesis but not to $P$. s. pv. tomato. These resulting progenies were phenotypically negative for pathogenicity and $\mathrm{HR}^{17}$. Since then, $h r p$ genes were found in $P$. s. pv. syringae ${ }^{13)}$, Ralstonia (Pseudomonas) solanacearum ${ }^{6}$, Erwinia amylovora ${ }^{28)}$ and some pathovars of Xanthomonas campestris ${ }^{1,5,30)}$. These hrp genes from different strains, species or genera hybridized to each other to varying degrees. In addition, amino acid sequences of several hrp gene loci have homology to secretion proteins of animal pathogens ${ }^{4,31}$. Interestingly, nonphytopathogenic $P$. fluorescens share homology with hrp gene loci from $P s t^{21)}$. These reports let us infer that sequences similar to $h r p$ genes are widely distributed in several bacteria and are differentiated to various functional genes at the evolutionary stage. On the other hand, a cluster of avrE genes from pv. tomato ${ }^{18)}$, avrPphE gene

\footnotetext{
* Plant Pathology Laboratory, Faculty of Agriculture, Shizuoka University, Ohya, Shizuoka 422-8529, Japan 静岡大学 農学部

** The United Graduate School of Agricultural Science, Gifu University, Yanagido, Gifu 501-1193, Japan 院連合農学研究科
} 
from $P s p^{20)}$ and $h r m A$ gene from pv. syringae ${ }^{11)}$ which are adjacent to a cluster of $h r p$ genes participating in the manifestation of pathogenicity. Pathogenicity to plants is one of the most important characters of $P$. syringae. Therefore, this region including the hrp genes and their neighbors could be used as significant factors for characterizing $P$. syringae.

Parts of $h r p$ genes have been used to compare

Table 1. Bacterial strains

\begin{tabular}{|c|c|c|c|}
\hline Species and pathovar & \multicolumn{2}{|c|}{ Strain } & \multirow{2}{*}{ Host or origin } \\
\hline Pseudomonas syringae & & \\
\hline pv. aceris & kaede1-1 & $(\# 440)$ & Acer buergerianum \\
\hline actinidiae & KW11 & (\# 320) PT & kiwi \\
\hline aptata & SB8601 & $(\# 560)$ & sugar beet \\
\hline atropurprea & NIAES1309 & (\# 1678) & Italian ryegrass \\
\hline coronafaciens & AVPCO8101 & (\# 196) & oat \\
\hline delphinii & PDDCC529 & PT & delphinium \\
\hline dendropanacis & kakuremino-1 & (\# 453) PT & Dendropanax trifidus \\
\hline eriobotryae & PERB8031 & (\# 930) & loguat \\
\hline glycinea & r0 & & soybeen \\
\hline japonica & BPST 802 & (\# 137) & barley \\
\hline lachrymans & cucum-1 & (\# 105) & cucumber \\
\hline lapsa & NCPPB2096 & PT & corn \\
\hline \multirow[t]{4}{*}{ maculicola } & ICMP3935 & PT & cauliflower \\
\hline & PMC8301 & & turnip \\
\hline & R101 & & radish \\
\hline & R1 & & radish \\
\hline “magnoliae”a) & PMG8101 & (\# 183) & magnolia \\
\hline mori & moril & (\# 131) & mulberry \\
\hline morsprunorum & U7805 & (\# 408) & peach \\
\hline myricae & yamamomo801 & (\# 166) & Japanese bay berry \\
\hline oryzae & $1-2$ & (\# 541) PT & rice \\
\hline \multirow[t]{2}{*}{ phaseolicola } & 3121 & & bean (15) \\
\hline & $\mathrm{KZ2W}$ & (\# 191) & kudzu vine \\
\hline photiniae & photinia-1 & (\# 733) & Photinia glabla \\
\hline pisi & pisum-1 & $(\# 679)$ & pea \\
\hline porri & ICMP8961 & & leak \\
\hline sesami & PSES-1 & (\# 1472) & sesame \\
\hline “spinaciae"a) & $\operatorname{spin} 8605$ & (\# 1449) & spinach \\
\hline striafaciens & avena2 & $(\# 110)$ & oat \\
\hline syringae & LOB2-1 & (\# 458) & lilac \\
\hline tabaci & $113 \mathrm{~A}$ & & tobacco \\
\hline theae & tea632 & (\# 68) & tea \\
\hline tomato & ICMP2844 & PT & tomato \\
\hline$(k i w i)^{\mathrm{b}}$ & KW741 & (\# 794) & kiwi \\
\hline$(\text { onion })^{\mathrm{c}}$ & ICMP3414 & & onion \\
\hline \multicolumn{4}{|l|}{ Pseudomonas } \\
\hline cichorii & TPS ash8101 & (\# 178) & tomato \\
\hline corrugata & TSN8212 & (\# 385) & tomato \\
\hline ficuserectae & L-7 & (\# 1391) T & Ficus erecta \\
\hline viridiflava & hakusai801 & $(\# 113)$ & chinese cabbage \\
\hline fluorescens & IFO3507 & (\# 1023) & \\
\hline aeruginosa & ZPB11 & $(\# 572)$ & \\
\hline \multicolumn{4}{|l|}{ Eshelicia } \\
\hline coli & B & & IAM1268e) \\
\hline & $\mathrm{DH} 5 \alpha^{\mathrm{d})}$ & & (24) \\
\hline
\end{tabular}

Numbers in parentheses correspond to collection number in the Shizuoka University Plant Pathology (SUPP) culture collection. PT, Pathotype strain. T, Type strain.

a) Pathovar names not validly published yet.

b) Unnamed pathovar from blossom rot of kiwi fruit.

c) Unnamed pathovar from bacterial leaf spot of onion.

d) This strain was used only for cloning.

e) This strain comes from the Institute of Applied Microbiology, the University of Tokyo. 
Table 2. Vector plasmids and clones

\begin{tabular}{|c|c|c|}
\hline & Relevant characteristics & Reference or source \\
\hline \multicolumn{3}{|l|}{ Plasmid } \\
\hline pGEM-7ZF $(+)$ & cloning vector, $\mathrm{Amp}^{\mathrm{r}}$ & Promega \\
\hline pLAFR3 & cosmid vector, $\mathrm{Tc}^{\mathrm{r}}$ & $(27)$ \\
\hline pPL6 & $\begin{array}{l}\text { pLAFR3 containing hrp cluster of } P \text {. syringae } \\
\text { pv. phaseolicola NPS } 3121\end{array}$ & (16) \\
\hline $\mathrm{pDC} 541$ & pLAFR3 containing $h r p$ and avrE cluster of $P$. syringae pv. tomato DC3000 & $(18)$ \\
\hline \multicolumn{3}{|l|}{ Genomic library } \\
\hline pSPlib.2 & pLAFR3 cosmid library of $P$. syringae pv. phaseolicola NPS3121 & $(16)$ \\
\hline pGlib. & pLAFR3 cosmid library of $P$. syringae pv. glycinea r0 & This study \\
\hline pMlib. & pLAFR3 cosmid library of $P$. syringae pv. maculicola PMC8301 & This study \\
\hline pTlib. & pLAFR3 cosmid library of $P$. syringae pv. tabaci $113 \mathrm{~A}$ & This study \\
\hline
\end{tabular}

homology and restriction fragment length polymorphism for grouping of $P$. syringae ${ }^{15,17,25)}$. However, a structural comparison of this entire large genomic region including the $h r p$ gene cluster has not been performed. Such a comparison might give us information on the structural similarity of the genomes of these organisms. This information is never obtained through single gene analysis and may reflect more precisely the history of organisms than single gene analysis.

In this study, we describe the utility of a comparison of large genomic regions including $h r p$ and its neighboring regions for grouping of $P$. syringae pathovars.

\section{MATERIALS AND METHODS}

Bacterial strains, plasmids, media and culture conditions Bacterial strains and plasmids are shown in Tables 1 and 2. Pseudomonas strains were grown in YP medium (yeast extract $5 \mathrm{~g}$, peptone $10 \mathrm{~g}$, water 1 liter, $\mathrm{pH} 6.8$ ) with or without agar at $27^{\circ} \mathrm{C}$. Escherichia coli strains were grown in Luria-Bertani (LB) medium ${ }^{19)}$ with or without agar at $37^{\circ} \mathrm{C}$. Antibiotics were used at $50 \mu \mathrm{g} / \mathrm{ml}$ for ampicillin and $30 \mu \mathrm{g} / \mathrm{ml}$ for tetracycline.

DNA preparation DNA was prepared as described by Ausubel et al. ${ }^{2}$. Genomic DNAs for Southern hybridization were extracted from pathovars of $P$. syringae and Pseudomonas spp. using the CTAB procedure. Plasmid DNA was isolated from $E$. coli using the boiling and alkaline lysis methods ${ }^{19)}$. Total DNA for construction of genomic libraries was prepared using the SDS-lysis method and purified by $\mathrm{CsCl} / \mathrm{EtBr}$ gradient centrifugation. Restriction fragments for subcloning and probes for Southern hybridization were isolated from agarose using Geneclean II kit (Bio101 Inc.) according to the manufacturer's instruction.

Cloning procedures Restriction fragments were cloned into pLAFR3 ${ }^{27)}$ or pGEM7f + . Ligation was performed with T4 DNA ligase as described by Ausubel et $a l^{2)}$. Packagene kit (Promega Biotech. Inc.) was used for in vitro packaging as recommended by the supplier.

Southern hybridization Southern hybridization was performed with a Genius kit (Boehringer Mann- heim). Template DNAs for probes (1-2 $\mu \mathrm{g})$ were labeled by random primed incorporation of digoxigenin-labeled dUTP. After DNA samples were digested with appropriate restriction endonucleases, 0.5 or $5 \mu \mathrm{g}$ DNA were electrophoresed in $0.7 \%$ agarose gels and transferred onto a nylon membrane. Hybridization was performed as recommended by the supplier for $16 \mathrm{hr}$ at $68^{\circ} \mathrm{C}$. The membranes were washed twice in wash buffer $1(2 \times$ $\mathrm{SSC}, 0.1 \% \mathrm{SDS}$ ) at room temperature for $5 \mathrm{~min}$ and then in wash buffer $2(0.5 \times \mathrm{SSC}, 0.1 \% \mathrm{SDS})$ at $68^{\circ} \mathrm{C}$ for $15 \mathrm{~min}$ before immunological detection.

Screening of clones including regions homologous to hrp gene and neighbor region The $17.0 \mathrm{~kb}$ EcoRI fragment from pPL6 containing hrp genes of $P s{ }^{16)}$ was used as the hybridization probe for screening clones from each genomic library. Selected clones and subclones were digested with appropriate restriction endonucleases and used as hybridization probes for genome walking. The cosmid clone pDC541 containing hrp and avrE genes of pv. tomato ${ }^{18)}$ was used to detect avrE genes from pv. maculicola (Psm).

\section{RESULTS}

\section{Comparison of restriction sites and homologous regions in four pathovars of $P$. syringae using selected clones}

Cosmid clones selected from the genomic library of $P s m$ covered a genomic region of over $80 \mathrm{~kb}$. Also, the clones from Psg, Psp and Pst covered over $100 \mathrm{~kb}$ of the region containing the $h r p$ genes of each pathovar. Genomic libraries of Psm did not yield any clones that linked $h r p D$ to $h r p E$ but they did hybridize with all $h r p$ genes probes from Psp. These clones were digested with appropriate restriction endonucleases, and restriction site maps were constructed (Fig. 1). Several DNA fragments from Psp and Psm were used as Southern hybridization probes (Fig. 2). Comparison of restriction sites the large genomic region revealed that the latter three pathovars closely resembled each other, whereas Psm was quite different from the three pathovars (Fig. 1). The map right outside the hrp homologous region of Psm closely resembled that of the avrE locus of pv. 


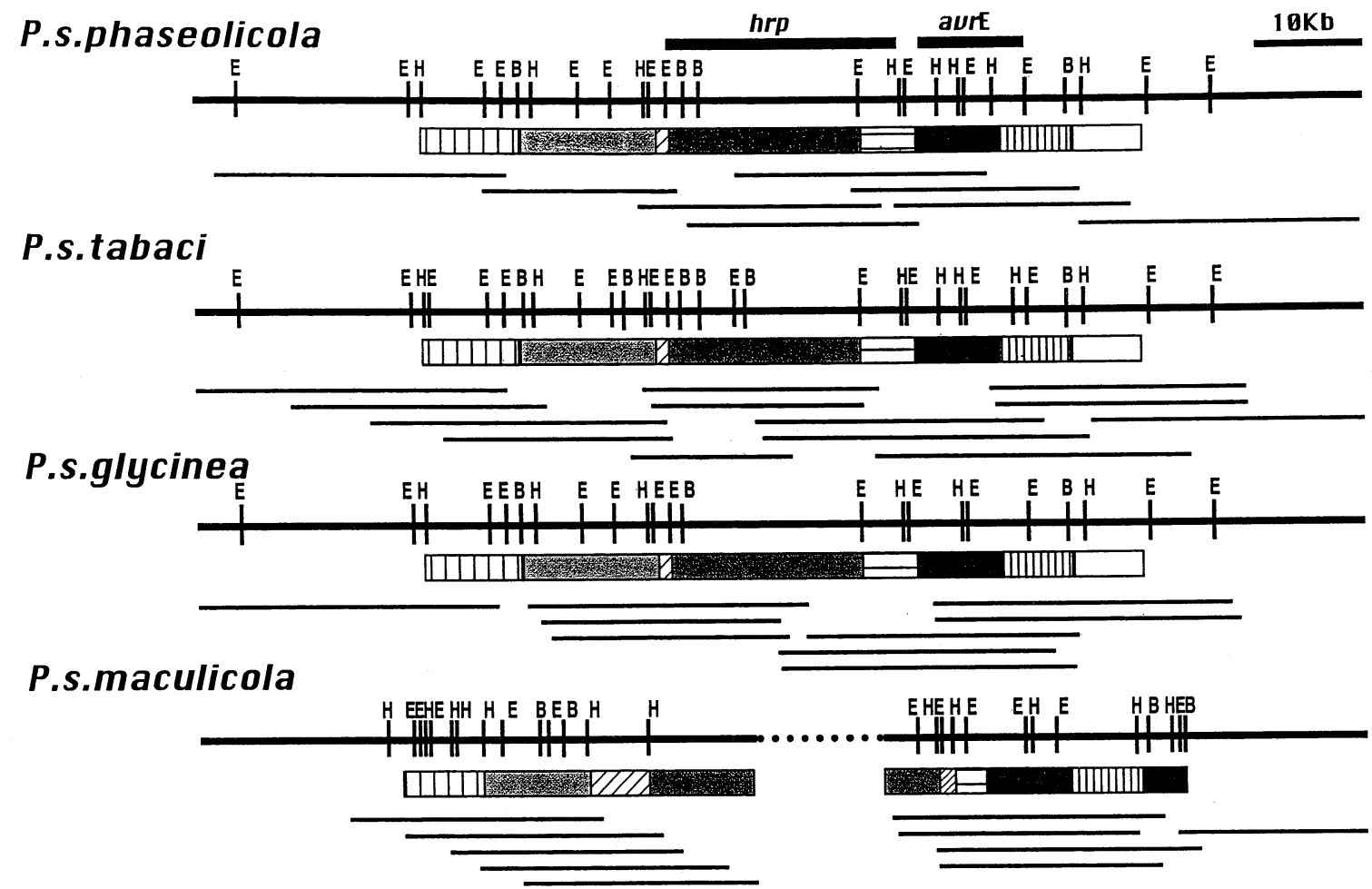

Fig. 1. Restriction enzyme map of Pseudomonas syringae pathovars. Filled patterns indicate homology region. Narrow lines mean getting clones. Dotted line is representation of a gap. Vertical lines and alphabet on the line mean the cutting site: B, Bam HI; E, Eco RI; H, HindIII.

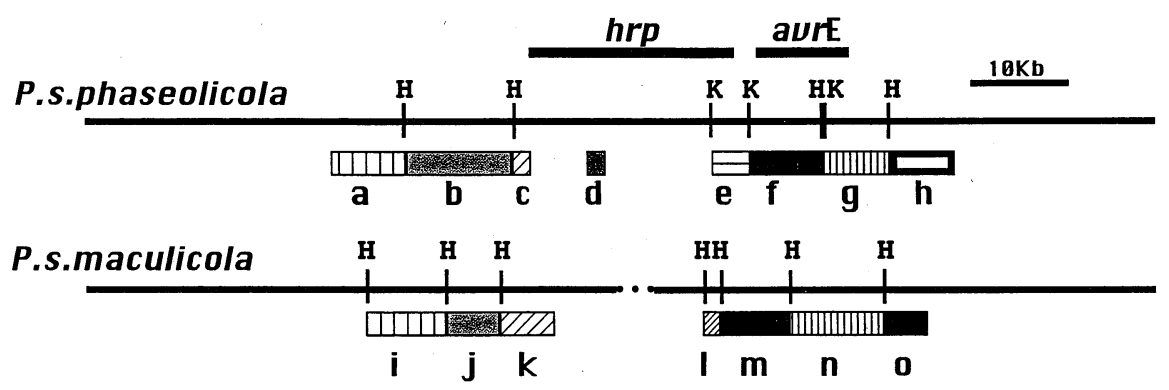

Fig. 2. Hybridization probes to compare homology in Pseudomonas syringae. Letters under filled patterns correspond to letters for probes in Tables 3 and 4. Letters on the vertical lines indicate restriction enzyme sites: H, HindIII; K, $K p n$ I.

tomato $^{18)}$. Hereafter, we tentatively refer to the "right or left" of the hrp region, devoting the direction containing $h r p R$ or $h r p L$, respectively. The cosmid clone pDC541 from pv. tomato strain DC3000 ${ }^{18)}$ involving avrE locus was hybridized to PSm clones (Fig. 2; 1, m and n). Further, parts of the DNA sequences in fragment 1 and $\mathrm{m}$ correspond to hrpS and transcription unit II of avrE. These results suggested that this region was equivalent to avrE. Furthermore, this region had homology to the other three pathovars in exactly the same position. The next right side of the deduced avrE regions of Psm (Fig. 2 , o) had no homology to the clones from the other pathovars. For the hrp gene cluster and its left outside, homologies were detected reciprocally by all probes used but hybridization signals varied in their patterns and strength. Fragments $\mathrm{j}$ and 1 from PSm were detected weakly, indicating homology signals against other pathovars.

Comparison of homology in hrp and its neighboring region among $P$. syringae

All hybridization probes from Psp and Psm were used to detect homologies among the various $P$. syringae pathovars listed on Table 3. Some probes (a,b and i), which are remotely located from the hrp gene cluster, hybridized to all bacterial species tested. Probes corresponding to the hrp region (c, d, e and $\mathrm{K}$ ) hybridized to all $P$. syringae strains with relatively homogeneous strength. Other probes (f, g, h, j, l, m, n and o) hybridized to a wide variety of strains belonging to $P$. syringae pathovars with significant variations in homology signal strength.

Patterns of hybridization signal strength grouped $P$. 
Table 3. Summary of hybridization results

\begin{tabular}{|c|c|c|c|c|c|c|c|c|c|c|c|c|c|c|c|}
\hline & \multicolumn{8}{|c|}{ Probes from pv. phaseolicola } & \multicolumn{7}{|c|}{ Probes from pv. maculicola } \\
\hline & $\mathrm{a}$ & $\mathrm{b}$ & $\mathrm{c}$ & $\mathrm{d}$ & $\mathrm{e}$ & $\mathrm{f}$ & $\mathrm{g}$ & $\mathrm{h}$ & $\mathrm{i}$ & $\mathrm{j}$ & $\mathrm{k}$ & 1 & $\mathrm{~m}$ & $\mathrm{n}$ & o \\
\hline P.s. phaseolicola ${ }^{\text {a) }}$ & + & + & + & + & + & + & + & + & + & + & + & - & + & + & - \\
\hline P.s.glycinea & + & + & + & + & + & + & + & + & + & + & + & - & + & + & - \\
\hline P.s.tabaci & + & + & + & + & + & + & + & + & + & + & + & - & + & + & - \\
\hline P.s.lachrymans & + & + & + & + & + & + & + & + & + & + & + & - & + & + & - \\
\hline P.s.mori & + & + & + & + & + & + & + & + & + & + & + & - & + & + & - \\
\hline P.s.dendropanacis & + & + & + & + & + & + & + & + & + & + & + & - & + & + & - \\
\hline P.s.eviobotryae & + & + & + & + & + & + & + & + & + & + & + & - & + & + & - \\
\hline P.s.myricae & + & + & + & + & + & + & + & + & + & + & + & - & + & + & - \\
\hline P.s.photiniae & + & + & + & + & + & + & + & + & + & + & + & - & + & + & - \\
\hline P.s.sesami & + & + & + & + & + & + & + & + & + & + & + & - & + & + & - \\
\hline P.s.?(kiwi) & + & + & + & + & + & + & + & + & + & + & + & - & + & + & - \\
\hline P.ficuserectae & + & + & + & + & + & + & + & + & + & + & + & - & + & + & - \\
\hline P.s.maculicola (R1) & + & + & + & + & + & + & + & + & + & + & + & - & + & + & - \\
\hline P.s.maculicola $a^{\mathrm{b})}$ & + & + & + & + & + & + & + & - & + & + & + & + & + & + & + \\
\hline P.s.tomato & + & + & + & + & + & + & + & - & + & + & + & + & + & + & + \\
\hline P.s.theae & + & + & + & + & + & + & + & - & + & + & + & + & + & + & + \\
\hline P.s.delphinii & + & + & + & + & + & + & + & - & + & + & + & + & + & + & + \\
\hline P.s.magnoliae & + & + & + & + & + & + & + & - & + & + & + & + & + & + & + \\
\hline P.s.actinidiae & + & + & + & + & + & + & + & - & + & + & + & + & + & + & + \\
\hline P.s.spinaciae & + & + & + & + & + & + & + & - & + & + & + & + & + & + & + \\
\hline P.s.syringae & + & + & + & + & + & + & + & + & + & + & + & - & + & + & - \\
\hline P.s.lapsa & + & + & + & + & + & + & + & + & + & + & + & - & + & + & - \\
\hline P.s.japonica & + & + & + & + & + & + & + & + & + & + & + & - & + & + & - \\
\hline P.s.aptata & + & + & + & + & + & + & + & + & + & + & + & - & + & + & - \\
\hline P.s.aceris & + & + & + & + & + & + & + & + & + & + & + & - & + & + & - \\
\hline P.s.pisi & + & + & + & + & + & + & + & + & + & + & + & - & + & + & - \\
\hline P.s.coronafaciens & + & + & + & + & + & + & + & + & + & + & + & - & + & + & - \\
\hline P.s.striafaciens & + & + & + & + & + & + & + & + & + & + & + & - & + & + & - \\
\hline P.s.?(onion) & + & + & + & + & + & + & + & + & + & + & + & - & + & + & - \\
\hline P.s.atropurprea & + & + & + & + & + & + & + & + & + & + & + & - & + & + & - \\
\hline P.s.oryzae & + & + & + & + & + & + & + & + & + & + & + & - & + & + & - \\
\hline P.s.porri & + & + & + & + & + & + & + & + & + & + & + & - & + & + & - \\
\hline P.s.morsprunorum & + & + & + & + & + & + & + & + & + & + & + & - & + & + & - \\
\hline P.viridiflava & + & + & - & - & + & - & - & - & + & - & - & - & - & - & - \\
\hline P.cichorii & + & + & - & - & + & - & - & - & + & - & - & - & - & - & - \\
\hline P.corrugata & + & + & W & + & $\mathrm{W}$ & - & - & + & + & + & - & - & - & - & - \\
\hline P. fluorescens & + & + & W & + & $\mathrm{W}$ & - & - & + & + & + & - & - & - & - & - \\
\hline P.aeruginosa & + & + & - & - & W & - & - & - & + & - & - & - & - & - & - \\
\hline E.coli & + & + & - & - & - & - & - & - & + & - & - & - & - & - & - \\
\hline
\end{tabular}

+ , Hybridization signal was ditected; -, Hybridization signal was not ditected; W, Not clear but broad and weak hybridization signal observed.

a) Containing two strains.

b) Containing three strains.

syringae strains into at least three types (Table 4). The first group contained strains of pvs. phaseolicola, glycinea, tabaci, lachrymans, mori, dendropanacis, eriobotryae, myricae, photiniae, sesami, an undetermined pathovar causing kiwifruit blossom rot disease and $P$. ficuserectae. This group (hereafter referred to as group I) showed strong homology to probes from Psp (f, g and h), and low homology to probes from Psm (j, l, m, n and o). The second group contained strains of pvs. maculicola, tomato, theae, delphinii, actinidiae, "spinaciae" and “magnoliae". In contrast to group I, this group (group II) showed strong homology to probes from Psm and moderate or no homology to probes from Psp. The third group is negatively defined as strains showing moderate or low homology to probes of either Psp or Psm. Therefore, this group will be referred to as group $U$ (U for "undetermined").

\section{DISCUSSION}

Comparison of homology and restriction sites of over $100 \mathrm{~kb}$ large genomic region demonstrated that Psp, Psg and $P s t$ are much alike not only in the $h r p$ gene cluster but also in its neighboring region. Previous reports 
Table 4. Summary of hybridization results

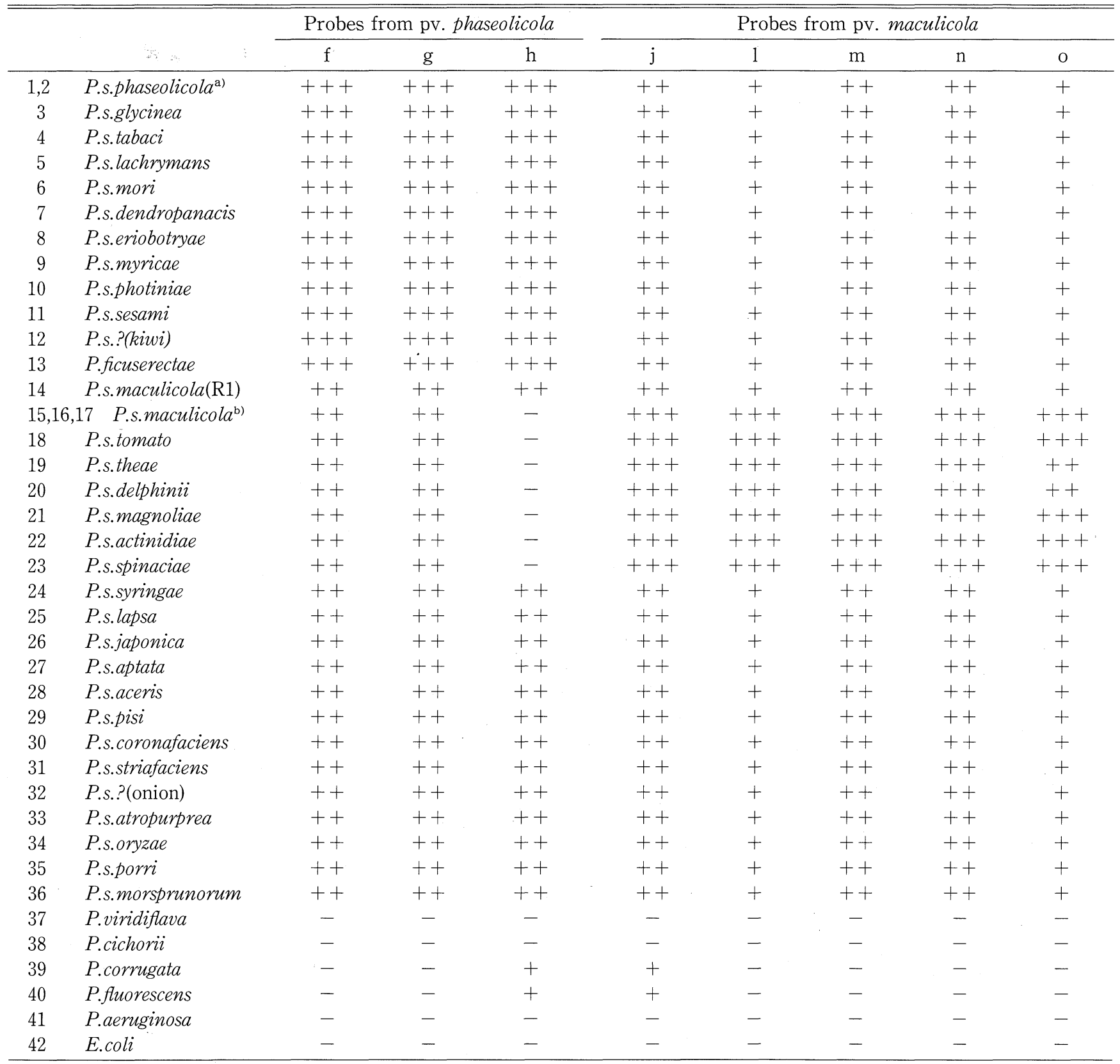

+++ , Strong hybridization signal was always ditected; ++ , Hybridization signal was ditected but not always at $0.5 \mu \mathrm{g}$ blotting; + , Weak hybridization signal was ditected but not always at $5 \mu \mathrm{g}$ blotting and was not ditected at $0.5 \mu \mathrm{g}$ blotting; -, No hybridization signal.

a) Containing two strains.

b) Containing three strains.

described that hrp genes of Psg and Pst can be mutated by marker exchange mutagenesis with the $h r p$ gene clone of Psp harboring a Tn5 insertion in it, and that these mutants can be restored to a wild-type phenotype upon introduction of clones carrying the corresponding wild-type locus from $P_{S} p^{17)}$. At the left outside of $h r p L$ region of $P S p$ exists avrPphE ${ }^{20)}$. This region was detected on Psp and Pst but not on Psg. On the contrary, our studies detected homology to this region in Psg and showed that restriction sites in this region are conserved. These results suggest that these three patho- vars are genetically closely related. On the other hand, Psm has a distinct restriction site map and different homology pattern from the other three pathovars. This result predicts that Psm may have differentiated from other pathovars belonging to the same $P$. syringae at an early time in evolution.

The restriction site map, DNA homology and DNA sequence led to the conclusion that the right end and right outside of the $h r p$ homologous region from Psm corresponded to $h r p Z$, hrpS and avrE region of $\mathrm{pv}$. tomato. Psm and pv. tomato closely resemble each other 


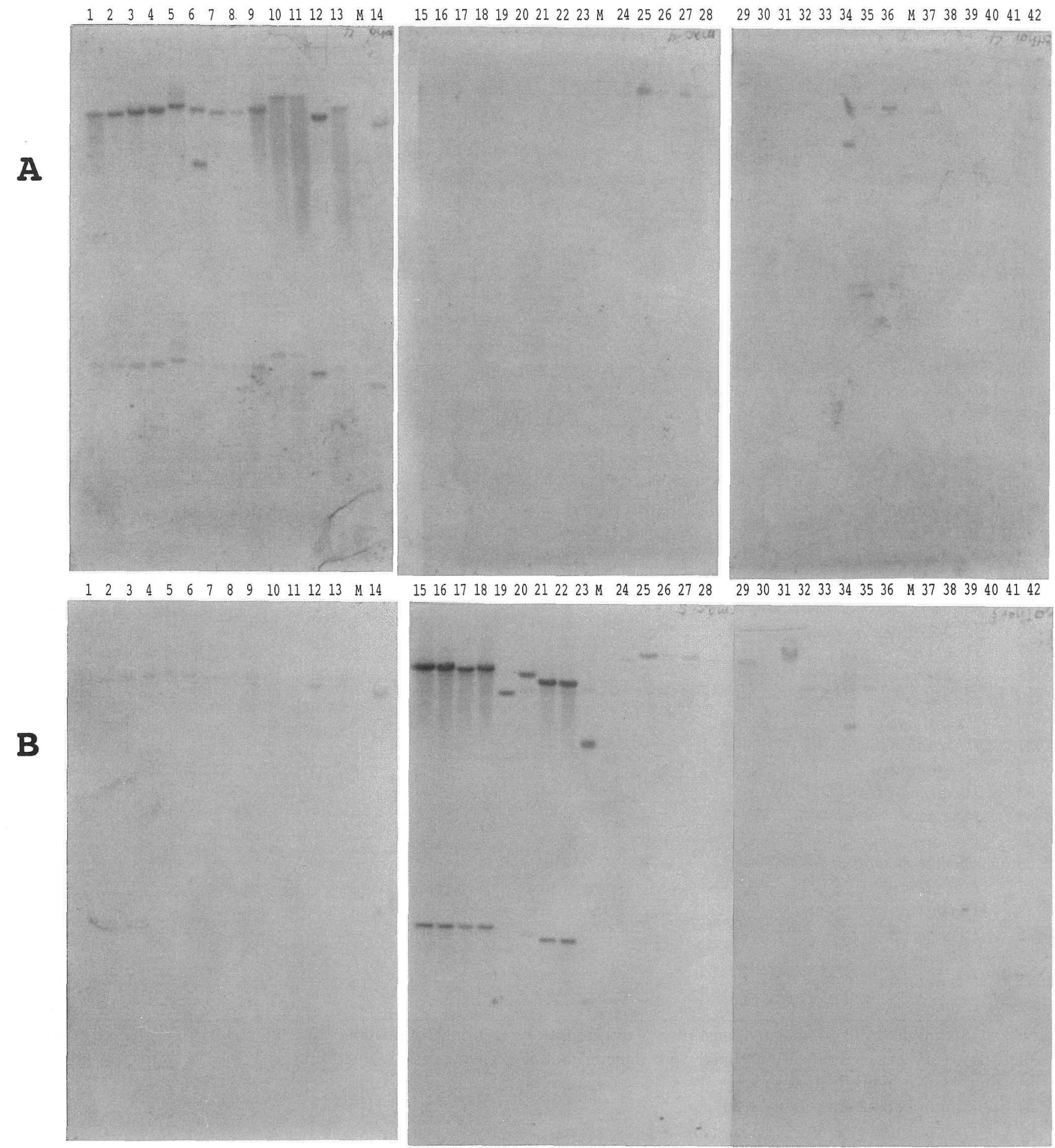

Fig. 3. Southern blot analysis of EcoRI-digested $5 \mu \mathrm{g}$ (upper row) or $0.5 \mu \mathrm{g}$ (lower row) of genomic DNA of Pseudomonas syringae strains using probe $\mathrm{h}(\mathrm{A})$ and probe o (B). Probe names are shown in Fig. 2. Lane numbers correspond to numbers of Table 4.

in several phenotypic characteristics ${ }^{29)}$. These results suggested that Psm and pv. tomato have a genetically close relationship. This genomic region of Psm is considered to be an avrE gene.

The $2.3 \mathrm{~kb}$ HindIII fragment containing the deduced $h r p S$ to $h r p Z$ genes from Psm (Fig. 2, 1) showed weak homology signals to $P_{s} p, P_{s g}$ and $P_{s t}$. The $h r p Z$ gene and its neighboring region encode harpin and secretion protein $^{23)}$. The $h r p Z$ from pv. tomato has high homology to $h r p Z$ from pv. syringae and Psg, but ORF1 (called $h r p A$ but not identical to $h r p A$ of $P s p$ ) has little homology to others. Therefore, this fragment showed weak homology signals to other strains.

At the right outside of the avrE region, homology signals were not continuously detected between $P_{s m}$ and the other three strains. However, clones containing loci 
homologous to this region of Psp but not continuing to the avrE region were isolated from a genomic library of Psm. These results suggest that gene rearrangement might occur in this region.

When parts of hrp and its neighboring region from Psp and Psm were used as hybridization probes, the strains of $P$. syringae classified into three groups named group I, group II and group U. Bacterial strains used in this study are the representatives of each pathovar or species. Some are pathotype or type strains as shown in Table 1, and others have been identified in our laboratory as typical through bacteriological and pathological properties. Therefore, we can speculate that this grouping may reflect relationships between each pathovar.

We had expected that the grouping of $P$. syringae pathovars based on the similarity of $h r p$ and neighboring genomic regions might reflect to some extent their pathogenicity, i.e. symptom and host range, and that the grouping might be contradictory, in some point to reported groupings based on phenotypic traits or total DNA homology. The result was unexpected as each of our three groups contained various types of pathovars having distinct host ranges and symptoms. Rather, our grouping agreed with those based on phenotypic traits and total DNA homology. For example, pvs. phaseolicola, glycinea, mori, lachrymans and tabaci are reported to form one group and pv. tomato, maculicola and delphinii are also suggested to form another group based on phenotypic traits and total DNA homologies ${ }^{12,22,26,29)}$. Our result coincided with those groupings and further assigned several more pathovars to each groups.

Concerning the pathogenic traits, one distinct feature can be identified. All tested strains causing knots or galls on trees are grouped in group I together with Psp and Psg. Another well-known gall-forming bacterium $P$. s. pv. savastanoi was not used in this study. Gardan et $a l{ }^{8)}$ reported by result of DNA-DNA hybridization that Psp and Psg were related to pv. savastanoi, which may support our hypothesis that $P$. syringae pathovars causing knot or galls are close allies. We are now preparing to investigate directly whether some strains of pv. savastanoi really belong to our group I.

Group I strains had similar RFLP patterns when digested with EcoRI, showing small number of restriction site variations; however, group II and group U had large variations in terms of RFLP patterns.

We used four strains of Psm which correspond to four groups of Psm. Takikawa et al. ${ }^{29)}$ reported that Psm is classified in four groups based on phenotypic and pathogenetic properties. In this study, one of them, strain R1 (group IV of Psm, corresponding to radish leaf-spotforming strains), was shown to be distinct on the basis of homology pattern of the hrp and its neighboring chromosome. Our unpublished data also suggested that the strains of the phenotypic group IV of Psm are distinct genetically, phenotypically and pathologically, showing the heterogeneity of Psm strains.

Three DNA probes from Psm, i.e. the right outside of the avrE region, the $2.3 \mathrm{~kb} H$ indIII fragments containing $h r p S$ through $h r p Z$ and the left outside of $h r p L$, specifically hybridized to the seven strains of group II, whereas the probe from Psp containing the right outside of the avrE region specifically hybridized to group I strains. These probes may be useful for discriminating homology groups, because they reflect not quantitative but qualitative differences.

Our study left fourteen strains as group U, i.e. unclassified. They are clearly heterogeneous, although some closely resembled each other. Among them, pv. syringae and pv. coronafaciens represent two more distinct groups, as suggested by our preliminary studies. Preparation of probes from these bacteria and a comparison of the homology of these groups are under way.

Our study may lead not only to developing rapid detection and identification methods but also to understanding the genetic structure and evolution of $P$. syringae group bacteria. In particular, the relationship between the evolution of $h r p$ genes and the evolution of the total genome is expected to be resolved.

This work was supported in part by the Grant-in-Aid for Scientific Research (No. 06660047) from the Ministry of Education, Science, Sports and Culture of Japan.

\section{Literature cited}

1. Arlat, M., Gough, C.L., Barber, C.E., Boucher, C. and Daniels, M.J. (1991). Xanthomonas campestris contains a cluster of $h r p$ genes related to the larger $h r p$ cluster of Pseudomonas solanacearum. Mol. Plant-Microbe Interact. $4: 593-601$.

2. Ausubel, F.M., Brent, R., Kingston, R.E., Moore, D.D., Seidman, J.G., Smith, J.A. and Struhl, K. (1992). Current Protocols in Molecular Biology, John Wiley \& Sons, New York.

3. Bereswill, S., Bugert, P., Volksch, B., Ullrich, M., Bender, C.L. and Geider, K. (1994). Identification and relatedness of coronatine-producing Pseudomonas syringae pathovars by PCR analysis and sequence determination of the amplification products. Appl. Environ. Microbiol. $60: 2924-2930$.

4. Bonas, U. (1996). hrp genes of phytopathogenic bacteria. In Bacterial Pathogenesis of Plants and Animals (Dangl, J.L. et al. eds.), Springer-Verlag, New York, pp. 79-98.

5. Bonas, U., Schulte, R., Fenselau, S., Minsavage, G.V., Staskawicz, B.J. and Stall, R.E. (1991). Isolation of a gene cluster from Xanthomonas campestris pv. vesicatoria that determines pathogenicity and the hypersensitive response on pepper and tomato. Mol. Plant-Microbe Interact. $4: 81-88$.

6. Boucher, C.A., Van-Gijsegem, F., Barberis, P.A., Arlat, M. and Zischek, C. (1987). Pseudomonas solanacearum genes controlling both pathogenicity and hypersensitivity on tobacco are clustered. J. Bacteriol. $169^{\prime}: 5626^{-}$ 5632.

7. Denny, T.P., Gilmour, M.N. and Selander, R.K. (1988). Genetic diversity and relationships of two pathovars of 
Pseudomonas syringae. J. Gen. Microbiol. 134: 19491960.

8. Gardan, L., Bollet, C., Abu Ghorrah, M., Grimont, F. and Grimont, P.A.D. (1992). DNA relatedness among the pathovar strains of Pseudomonas syringae subsp. savastanoi Janse (1982) and proposal of Pseudomonas savastanoi sp. nov. Int. J. Syst. Bacteriol. 42 : 606-612.

9. Guillorit-Rondeau, C., Malandrin, L. and Samson, R. (1996). Identification of two serological flagellar types (H1 and H2) in Pseudomonas syringae pathovars. Eur. J. Plant Pathol. 102 : 99-104.

10. Hendson, M., Hildebrand, D.C. and Schroth, M.N. (1992). Relatedness of Pseudomonas syringae pv. tomato, Pseudomonas syringae pv. maculicola, and Pseudomonas syringae pv. antirrhini. J. Appl. Bacteriol. 73 : 455-464.

11. Heu, S. and Hutcheson, S.W. (1993). Nucleotide Sequence and Properties of the hrmA locus associated with the Pseudomonas syringae pv. syringae 61 hrp gene cluster. Mol. Plant-Microbe Interact. 6 : 553-564.

12. Hildebrand, D.C., Schroth, M.N. and Huisman, O.C. (1982). The DNA homology matrix and non-random variation concepts as the basis for the taxonomic treatment of plant pathogenic and other bacteria. Annu. Rev. Phytopathol. 20 : 235-256.

13. Huang, H.-C., Schuurink, R., Denny, T.P., Atkinson, M. M., Baker, C.J., Yucel, I., Hutcheson, S.W. and Collmer, A. (1988). Molecular cloning of a Pseudomonas syringae pv. syringae gene cluster that enables Pseudomonas fluorescens to elicit the hypersensitive response in tobacco plants. J. Bacteriol. $170: 4748-4756$.

14. Janse, J.D., Rossi, P., Angelucci, L., Scortichini, M., Derks, J.H.J., Akkermans, A.D.L., Vrijer, R. and Psallidas, P.G. (1996). Reclassification of Pseudomonas syringae pv. avellanae as Pseudomonas avellanae (spec.nov.), the bacterium causing canker of hazelnut (Corylus avellana L.) system. Appl. Microbiol. 19 : 589-595.

15. Legard, D.E., Aquadro, C.F. and Hunter, J.E. (1993). DNA sequence variation and phylogenetic relationships among strains of Pseudomonas syringae pv. syringae inferred from restriction site maps and restriction fragment length polymorphism. Appl. Environ. Microbiol. $59: 4180-4188$.

16. Lindgren, P.B., Peet, R.C. and Panopoulos, N.J. (1986). Gene cluster of Pseudomonas syringae pv. "Phaseolicola" controls pathogenicity of bean plants and hypersensitivity on nonhost plants. J. Bacteriol. 168: 512-522.

17. Lindgren, P.B., Panopoulos, N.J., Staskawicz, B.J. and Dahlbeck, D. (1988). Genes required for pathogenicity and hypersensitivity are conserved and interchangeable among pathovars of Pseudomonas syringae. Mol. Gen. Genet. 211: 499-506.

18. Lorang, J.M. and Keen, N.T. (1995). Characterization of avrE from Pseudomonas syringae pv. tomato: a $h r p$ linked avirulence locus consisting of at least two transcriptional units. Mol. Plant-Microbe Interact. 8 : 49-57.

19. Maniatis, T., Fritsch, E.F. and Sambrook, J. (1982). Molecular cloning. A Laboratory Manual, Cold Spring Harbor Laboratory Press, Cold Spring Harbor, New York.

20. Mansfield, J., Jenner, C., Hockenhull, R., Bennett, M.A. and Stewart, R. (1995). Characterization of avrPphE, a gene for cultivar-specific avirulence from Pseudomonas syringae pv. phaseolicola which is physically linked to $h r p Y$, a new $h r p$ gene identified in the halo-blight bacterium. Mol. Plant-Microbe Interact. 7 : 726-739.

21. Mulya, K., Takikawa, Y. and Tsuyumu, S. (1996). The presence of regions homologous to $h r p$ cluster in Pseudomonas fluorescens PfG32R. Ann. Phytopathol. Soc. Jpn. 62 : 355-359.

22. Pecknold, P.C. and Grogan, R.G. (1973). Deoxyribonucleic acid homology groups among phytopathogenic Pseudomonas species. Int. J. Syst. Bacteriol. 23 : 111-121.

23. Preston, G., Huang, H.-C., He, S.Y. and Collmer, A. (1995). The $h r p Z$ proteins of Pseudomonas syringae pvs. syringae, glycinea and tomato are encoded by an operon containing Yersinia ysc homologs and elicit the hypersensitive response in tomato but not soybean. Mol. Plant-Microbe Interact. 8 : 717-732.

24. Sands, D.C., Schroth, M.N. and Hildebrand, D.C. (1970). Taxonomy of phytopathogenic pseudomonads. J. Bacteriol. 101 : 9-23.

25. Scholz, B.K., Jakobek, J.L. and Lindgren, P.B. (1994). Restriction fragment length polymorphism evidence for genetic homology within a pathovar of Pseudomonas syringae. Appl. Environ. Microbiol. 60 : 1093-1100.

26. Schroth, M.N., Bitanza, V.B. and Hildebrand, D.C. (1971). Pathogenic and nutritional variation in the halo blight group of fluorescent pseudomonads of bean. Phytopathology $61: 852-857$.

27. Staskawicz, B.J., Dahlbeck, D., Keen, N. and Napoli, C. (1987). Molecular characterization of cloned avirulence genes from race 0 and race 1 of Pseudomonas syringae pv. glycinea. J. Bacteriol. 169 : 5789-5794.

28. Steinberger, E.M. and Beer, S.V. (1988). Creation and complementation of pathogenicity mutants of Erwinia amylovora. Mol. Plant-Microbe Interact. 1 : 135-144.

29. Takikawa, Y., Nishiyama, N., Ohba, K., Tsuyumu, S. and Goto, M. (1992). Synonymy of Pseudomonas syringae pv. maculicola and Pseudomonas syringae pv. tomato. In Plant Pathogenic Bacteria, June 9-12, 1992 (Lemattre, M., Freigoun, S., Rudolph, K. and Swings, J.G. eds.), INRA, Versailles Cedex, France, pp. 199-204.

30. Waney, V.R., Kingsley, M.T. and Gabriel, D.W. (1991). Xanthomonas campestris pv. translucens genes determining host-specific virulence and general virulence on cereals identified by $\operatorname{Tn} 5$-gusA insertion mutagenesis. Mol. Plant-Microbe Interact. 4 : 623-627.

31. Willis, D.K., Rich, J.J. and Hrabak, E.M. (1991). hrp genes of phytopathogenic bacteria. Mol. Plant-Microbe Interact. $4: 132-138$.

\section{和 文 摘 要}

井上康宏・瀧川雄一：hrp 遺伝子群およびその周辺領域の相 同性の比較によるPSeudomonas syringae 群細菌の類別

P. syringae 群細菌の病原型（pathovar）間の遺伝子レベル での相違を調査するために，P. S. pv. glycinea (Psg), pv. maculicola (Psm), pv. phaseolicola (Psp), pv. tabaci (Pst) の遺伝子ライブラリーより hrp 遺伝子とその周辺領域のクロー ンを選抜し，DNA の相同性と制限酵素地図の比較を行った。 $P s g, P s p, P s t$ は調査した全領域において相同性が高く, 制限酵 素地図がよく一致していたが，Psm は相同性は認められるもの 
の制限酵素切断部位は全く異なっていた。hrpRS の右外側領域 はすべての菌株において P. s. pv. tomato から分離報告されて いる $a v r E$ 領域と相同性を示した。avrE 相同領域の外側では $P S m$ と他の菌株との間に相同性が検出できなかった。他の $P$ syringae 群細菌の病原型間においてPsp とPsmより作成した プローブを用いてゲノミックサザンを行った結果，hrp 領域の
周辺においては, 比較的均一で高い相同性が確認された。avrE 相同領域およびその外側領域ではP Psp 由来のプローブと高い相 同性を示すグループ (group I)，PSm 由来のプローブと高い相 同性を示すグループ (group II)，いずれに対しても相同性を検 出できないか低い相同性のみを示すグループ (group U) に類別 された。 